\title{
Some Anthropic Aspects in Meridional Region of Sebdou (Oran-Algeria)
}

\author{
Noury Benabadji1, Amina Benabadji Bouchenak-Khelladi2*, Regagba Zineb³, \\ Khelladi Medarbal ${ }^{3}$ \\ ${ }^{1}$ University of Tlemcen, Tlemcen, Algeria \\ ${ }^{2}$ Department of Literature and Human Sciences, Tlemcen University, Tlemcen, Algeria \\ ${ }^{3}$ University of Tiaret, Tiaret, Algeria \\ Email: benabadji n@yahoo.fr, ${ }^{*}$ bouchenakamina@yahoo.fr
}

Received 26 May 2014; revised 31 July 2014; accepted 19 August 2014

Copyright (C) 2014 by authors and Scientific Research Publishing Inc.

This work is licensed under the Creative Commons Attribution International License (CC BY). http://creativecommons.org/licenses/by/4.0/

(c) (i) Open Access

\section{Abstract}

Relying essentially on human data (social structure, demography, population repartitions, migratory movements, agro-pastural activities), the authors, from their studies, note that these regions are an extension of hamlets and other groups. Highlands gather a small population that seems to settle. Responsible human disturbance (clearings, cultures, urbanization, etc.) modified a large part of the actual state of vegetation structures. The results also show that most of the population is concentrated in the main towns. This concentration causes consumption of pre-forest land and rangelands. The average annual extension can sometimes reach $2.4 \mathrm{Ha}$. Hamlets, home grouping seem to impose a lifestyle approaching that of centers located in the North. At the bioclimatic level, the results show that the cold thermal variations promote contact between woody vegetation and steppe formations with thermal determinism (formation often in xerophytes thorny pads). Droughts often advocate regressive dynamics of these plant formations which are quite degraded. On the other hand, stressing continuity issues related to human actions, the authors present the floristic composition, detailing the botanical plant species including biological and morphological types. The therophyte type predominates in all areas explored and their percentage can reach $73 \%$ in the steppe and $49 \%$ in Beni-Snous.

\section{Keywords}

Human actions, Steppe, Flora, Botanical Characterization, Beni-Snous, El-Aricha (Algeria)

\footnotetext{
"Corresponding author.
} 


\section{Introduction}

After independence in 1962, the Algerian forest has gradually found its hangouts, but it is certain that the impact of human action on the natural landscape remains present and uncontrolled.

Recovery and development of this heritage can not be conceived in a purely ecological context, only if the socio-economic aspect contributes effectively in the state of ecosystem stability.

Mountain societies, all over the world, have always used ingenuity to enhance their profit, resources often limited in hard environment.

In general, the Mediterranean region, and in particular that of Beni-Snous and El-Bayadh remain submitted to a strong destruction of ecosystems which can be the consequences of human activities pressure which is exercised with intensity on the natural environment.

Barbero, et al. [1] reported changes that occurred for certain climatic parameters. Amplification of the summer drought in the suboréal-Subatlantic hinge contributed to a seasonal aridity of climate which, at least for Mediterranean coastal and coastal juxta areas, could influence a restructuring of biological material of forest ecosystems, by modifying interspecific competition processes and promoting the establishment of mixed forests, as it is the case today in the old population growth. The arrival of herbaceous species is not compatible in the ecosystem with maintaining some sclerophyllous species and the development of pink laurel (Nerium oleander) species of meso-thermal which have been limited by the repeated human use of forest ecosystems. Stages of further degradation of these formations distinguish very open landscapes.

Anthropogenic disturbances are for a large part responsible for the current state of vegetation structures in the Maghreb Barbero, et al. [2].

The ecological study of the vegetation is primarily a study of the action of man on vegetation Long [3].

Demography is one of the main causes of degradation of these environments. It has been exploded since the beginning of the century. The population almost doubles every 20 to 30 years, depending on the country, 25 years on average, especially since the 50s. Therefore, more land must be cultivated, more animals must be adopted, and more wood must be cut for heating.

In addition most countries experience a significant improvement in living standards and a certain urbanization. Demand for meat and cereal products has increased even faster than population, which further exacerbates the pressures on land.

Pastoral societies especially in steppe areas have faced the mounted state, introduced by colonization. It is the state that holds the power. As a result, traditional institutions have become unnecessary and disappeared. Young states have pursued the same policy of consolidation of state structures. The semi-nomadic societies, considered retrograde, are forced to settle down in the steppe because of the problem of political control Regagba [4].

To capture the effect of human action and threats that significantly affect our study area (mountain and steppic areas), we found it necessary to study the population evolution, bioclimate, agricultural activities, the state of vegetation, and overgrazing charged on the environment.

\section{Materials and Methods}

\subsection{Geographic Situation (Figure 1, Table 1)}

Administratively, the region of Beni-Snous including the surrounding high lands, is split between the wilaya of

\begin{tabular}{cccc} 
Table 1. Location of study areas. & & \\
\hline Stations & Latitude North & Longitude West & Altitude (m) \\
\hline Beni-Snous & $34^{\circ} 47^{\prime}$ & $1^{\circ} 26^{\prime}$ & 1270 \\
Tlemcen & $34^{\circ} 57^{\prime}$ & $1^{\circ} 17^{\prime}$ & 592 \\
Sebdou & $34^{\circ} 38^{\prime}$ & $1^{\circ} 20^{\prime}$ & 720 \\
El-Aricha & $34^{\circ} 27^{\prime}$ & $1^{\circ} 34^{\prime}$ & 1280 \\
Naama & $33^{\circ} 15^{\prime}$ & $0^{\circ} 64^{\prime}$ & 1100 \\
El-Bayadh & $33^{\circ} 40^{\prime}$ & $1^{\circ} 34^{\prime}$ & 1150 \\
\hline
\end{tabular}



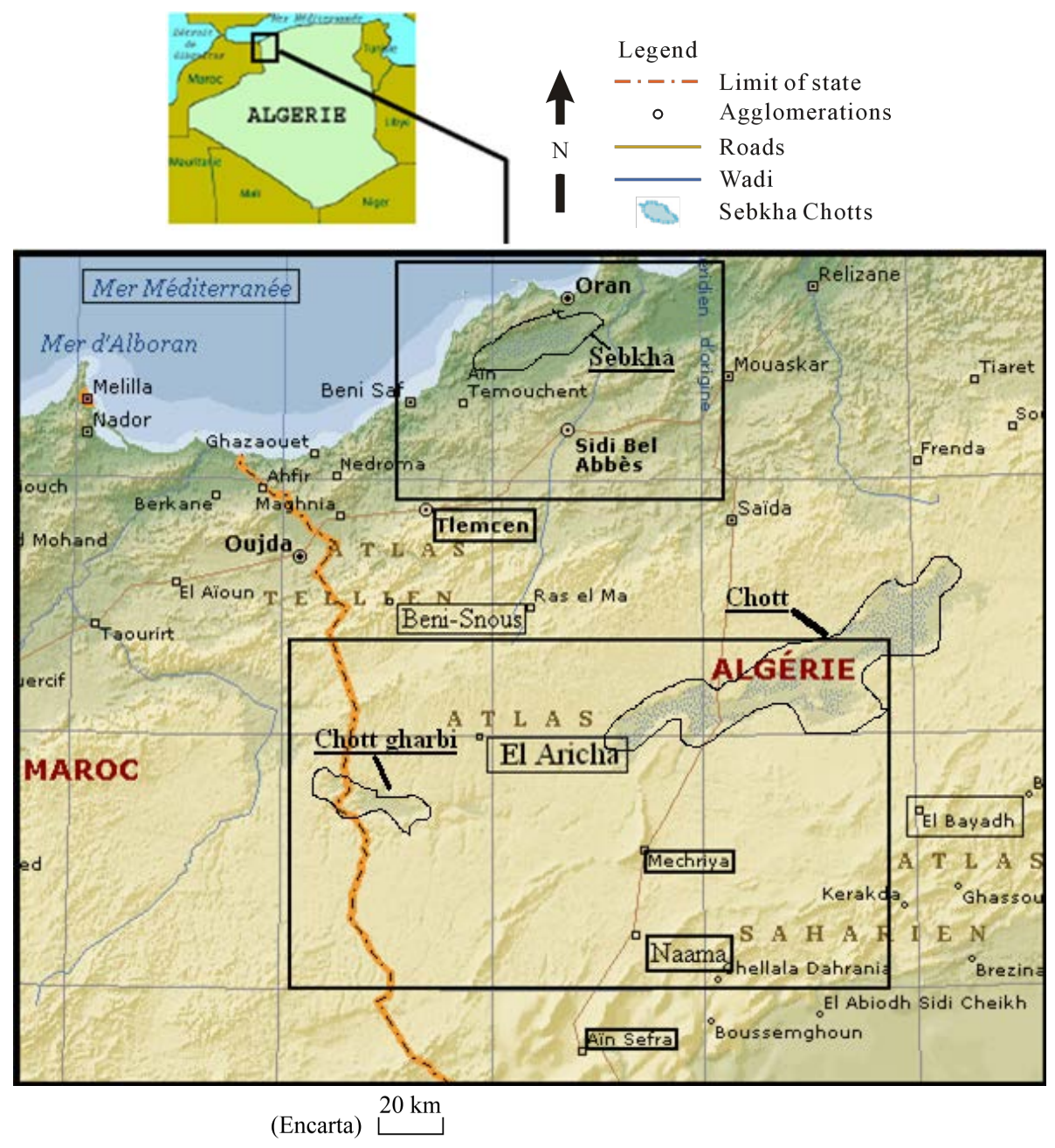

Figure 1. Location of pre-forest and steppic areas.

Tlemcen and Naama. Beni-Snous is only a part of Tlemcen mountains, of which the chain of the direction Northeast/Southwest, goes far to the north and south of this map (Figure 1). In other words, the Tell Atlasis composed of several parallel mountains whose northern most is the one that dominates Tlemcen (Djebel-Sakretine, Lalla-Setti land) and continues in the west with the heights of Zarifet. Immediately in the south of this mountain, the long area of Terni is spread, bounded on the South by a second mountain, that of Ain Ghoraba.

By the south side of the latter, extended by the forest mountain of Hafir, that we get here on the map. BeniSnous (pre-forest area) and the high plains between El-Aricha and El-Bayadh, lie between the mountains of the Tell Atlas where mountains peak (Tenouchfi $1843 \mathrm{~m}$ Dourdaz $1463 \mathrm{~m}$ ) and those of the Saharan Atlas where rises mountain of Aissa $2236 \mathrm{~m}$ located near Ain Safra). The region is limited by Morocco state in the West and in the East by the Chott E-Chergui. It is bordered by latitudes $34^{\circ} 38^{\prime}$ and $33^{\circ} 33^{\prime}$ in the North, and longitudes $0^{\circ} 20^{\prime}$ in the East and $1^{\circ} 30^{\prime}$ in the West. It is crossed by the national road 22 connecting Tlemcen to Bechar through agglomerations of Mechria, Naama and Ain Safra. The altitudinal range of the region of Beni-Snous reaches $1250 \mathrm{~m}$, that of the high plains varies between 1000 and $1200 \mathrm{~m}$.

\subsection{Geology and Morphology}

\subsubsection{Mountain Ranges of Beni-Snous}

The geological approach that we are going to deal with is related to the works of Benest and Elmi [5], this one says that the mountains are formed of cracked limestone. The rocks of these mountains are based on porous sand stone, lying themselves on clays and marls. Their tops, always flat, are lime stone lands, as those located in im- 
mediate vicinity of Tlemcen: Lalla Setti, Ain Fezza. It is a formation consisting mainly of limestone and dolomite alternating with beds of marl and sand stone. The primary bed rock forms the base of the High Plains, which consist of conglomerate sand lacustrine limestones in a collapsed compartment of secondary land. Mountains of Sidi-Djilali correspond to a northern advanced of high plains of the high lands Benest [6]. Furthernorth the Jurassic Mountains of Tell separates the plain of Moulouya (situated in Moroccan territories).

Lithology briefly presented in this study can have some preponderant influence on the pedogenesis in semiarid place, in one hand, and on some conditions of plant life on the other hand.

\subsubsection{Depression of the High Lands (El-Aricha, El-Bayadh)}

This depression is full largely by quaternary material of alluvial origin. In his study of the plain of Moulouya, Ruellan [7], reports the relationship which exists between ground types in the one hand and shapes and deposits on the other hand. Quaternary formation are organized in nested terraces along the wadis, in particular the glaze terraces. These formation contain calcareous brown soil with calcareous accumulation, localized on quaternary glaze, they are characterized by a small deepness $(20$ to $50 \mathrm{~cm})$ a sandy loam texture, a rate of organic matter under $2 \%$, an absorbent complex saturated in magnesium and calcium and a vegetation based on Stipa tenacissima, Artemisia herba-alba, Lygeum spartum...

Steppic ground are significant in the majority of plains from Sebdou to El-Bayadh via El-Aricha till semi-arid valley, by the number of their characters, they can remind of chestnut ground, brown ground and the Sierozems of Russia Aubert [8]. However, Duchaufour [9] precised that all soils of the steppe belong to the iso-humic soils. In these steppes and the steppe of El-Bayadh region, we find a considerable area occupied by shallow soils, these are:

- Raw mineral soils and little evolved of erosion on the mountains and outcrop of geologic substratum.

- Calcimagnesic soils with slab, calcareous crust or crusting on encrusted glaze of old or middle quaternary.

In steppic environment of North Africa, we often find grounds with salinity, either on source rocks containing a high content in salts, or in the endorheic depressions (Chotts and Sebkhas). Halophytic vegetation can cover larges areas.

Analytic results obtained from some mountain soils of Beni-Snous:

- A silty clay texture ( $50 \%$ sand, $27 \%$ silts and $23 \%$ clays)

- An average content in limestone (16\% to $20 \%)$

- A higher organic matter (more than $2 \%$ )

- According to Munsell, the color is presented as follows: 7.5YR 3/2 and 5YR 2/6.

- Hp is alcalin, it exceeds 7.7.

Analytic results of soils obtained from some high lands:

- A siltyclay texture ( $75 \%$ sand, $15 \%$ silts and $10 \%$ clays)

- A higher content in limestone (35\% to $42 \%)$

- A weak organic matter (under $2 \%$ )

- According to Munsell, the color is presented as follows : 5YR 5/6 and 5YR 5/4.

- $\mathrm{pH}$ is alcalin, (it exceeds 7.7).

\subsection{Bioclimate}

In order to know the bioclimatology of our place of study, we referred to the data of Seltzer [10] and that of national office of meteorology of Oran for the period of 1980-2008.

The combination of climatic parameters (precipitations and temperature). They constitute the hinge of climate because they influence vegetation by giving its typology Bary-Lenger, et al. [11]. These parameters helped many authors for the development of several indices which indicate the climate and existant vegetation, especially the classification of Debrach, the theombrothermic diagrams and pluviothermic Emberger Quotient.

According to the classification of Debrach [12], the climate of Beni-Snous is semi-continental $\left(\mathrm{M}-\mathrm{m}=28^{\circ} \mathrm{C}\right)$, that of the high lands is continental (El-Aricha $\left.\mathrm{M}-\mathrm{m}=35.77^{\circ} \mathrm{C}\right)$.

\subsubsection{Ombrothermic Diagrammes.}

They are used to determine the length of the dry period of the year, by considering the dry month when $\mathrm{P}=2 \mathrm{~T}$, $\mathrm{P}=$ average rainfall in $\mathrm{mm}, \mathrm{T}=$ middle temperatures of the same year in ${ }^{\circ} \mathrm{C}$. In order to visualize these diagrams, 
Bagnouls et Gaussen [13] propose a method which consists of focusing on the same graph the temperature and the pluviometry so that the scale of temperatures doubles that of precipitations, by considering the drought when the curve of precipitations goes under the curve of temperatures. The region of Beni-Snous presents a period more or less dry during the year, it lasts 6 months, that of the central land exceeds ten months of the year. These periods of drought coincide with the summer period, including, sometimes a part of spring and another part of autumn. The duration of drought is strongly influenced by the altitude, the temperatures increase tardily at the level of these mountainous slopes and increase earlier on the coastline.

\subsubsection{Pluviothermic Emberger Quotient}

Used in northern Africa and in the Mediterranean countries, this quotient remains an essential tool for characterizing the bioclimate of a region. By using a two-dimensional diagram in which the value of quotient of a determined locality is in ordinate and the average of the coldest month of the year in abscisse.

This quotient allows you to view the position of the meteorological stations and to delimit the bioclimatic period of plant species or a vegetal group and to make any comparison. It was formulated as follows:

$$
\mathrm{Q}_{2}=2000 \mathrm{P} / \mathrm{M}^{2}-\mathrm{m}^{2}
$$

$\mathrm{P}$ = yearly medium precipitations in $\mathrm{mm}$;

$\mathrm{M}=$ Average of maxima of the hottest month in (Kelvin);

$\mathrm{m}=$ Average of minimas of the coldest month in (Kelvin).

- The climagramme shows that the mountainous bioclimate of Beni-Snous is semi-arid and higher with a tempered winter, only in high altitude where it is sub-humid lower with tempered winter variant $\left(\mathrm{Q}_{2}=66.51\right.$ et $\mathrm{m}=5.4 \mathrm{C}^{\circ}$ ). The fresh semi-arid appears in places of more than $400 \mathrm{~m}$ of altitude and spreads until the steppe. In steppic area, the bioclimate differs from the Saharan bioclimatic stage higher than arid bioclimatic stage with cold winter variant $\left(\mathrm{Q}_{2}=36.51\right.$ and $\left.\mathrm{m}=-1{ }^{\circ} \mathrm{C}\right)$.

We conclude (that the climate of the region is typically Mediterranean, where there are essentially two bioclilmatic stages, the semi-arid which is the most spread, and the arid, with a hot and dry season in contrast with a cold rainy season. The actual rainfall precipitations on the mountains vary between $350 \mathrm{~mm}$ and $480 \mathrm{~mm}$, this is what explains rusticity of vegetal species (Pinus halepensis, Olea europea, Ziziphus lotus, Juniperus oxycedrus) of the region. The climate parameters have a certain and direct influence on the development of vegetal species. Two principal parameters were always taken into consideration; rainfall precipitations and the temperature.

\subsection{Sampling Methods (Flora)}

Vegetation surveys are realized according to classical methods, by establishing a list of all the species on an area unit set beforehand within a homogeneous station, by giving two indices to every species: abundance, dominance, and sociability.

In order to know the floristic composition of the area of study, twenty phytoecologic surveys were respectively realized at the level of pre forest mountains around Beni-Snous and in steppic areas during the lasts years (2011 to 2014), when everyone has the woody species list accompanied with a set of ecologic and physionomic information. The number of inventoried species rises to 158 in Beni-Snous and to 60 at the level of the steppe.

Taxa identification was made from the flora of Maire [14], that of Quézel and Santa [15] and of Bonnier [16]. After they have been classified by family, the inventoried species were characterized botanically.

The inventoried species were subjected to characterization. The species counting is made on the totality of inventoried species in each station of the two regions.

- Morphologic, distinguishing wood types, perennial types and annual herbaceous.

- Biological, distinguishing biological types (Thérophytes, Chamaephytes, Géophytes, Hémicryptophytes et Phanérophytes) according to Raunkiaer [17].

\subsection{Anthropic Actions}

In our study, we devoted an important part to anthropization, this is how the data related to population, human activities of two regions as the social structure, demography, migratory movements, overgrazing, of town hall, from magister works of Benabadji Bouchenak [18] of Boukhoza [19] and Bourdieu [20] and the investigations made on sites of study from population after many missions made. 


\section{Results and Discussions}

\subsection{Population of the Region}

A small berber islet in western Algeria, situated between Tlemcen and Moroccan border. Linguistically, as mentioned by Salem Chaker [21], Beni-Snous can be related to the rifain set, and more particularly Beni-Iznassen, with whom they share many particularities. Roger Bellissant [22] mentioned that the population of Beni-Snous belonged to the Azail who occupy this picturesque region. In the past, it was composed of four tribes Azaïls, El-Khémis and its surroundings, Kef and Béni-Bou Saïd. Whereas now, it is composed of El-Khemis and its dependances and Azail. Every social structure, has its own name referring to its ancestor. The group members considered themselves as the ancestor descendants of whom they often take the noun. El-Khemis is the capital of the region and the noun of the tribe. Built on the edge of wadi El-Khemis, Beni-Snous possesses an uphill and below a suburb of many villages of which it is the economic center, because it is in El-Khemis where the only market is held. And it is the political center because this is where the caîd lives. These villages are, from douwn stream to upstream: the Wadi, Beni Hammou, Oulad Moussa, Oulad Arbi, Béni Achir, Dehar Ayed, Béni Zidaz, and further Sidi Larbi et Mazzer. All these villages exist thanks to the presence of wadi El-Khemis. It brought the small alluvial that the berbers cultivate in these wild places. Below toward meridional zone, particularly on the steppic plains, there are two kinds of populations; Ouled Nehar Ghoraba who occupy the western part of the region (Magoura, Sidi Djilali), Ouled Nehar Cheragua occupy Aricha areas. According to the kind of life, we can distinguish between the nomads and semi-nomadic people; desert for the firsts and steppe for the seconds who seem to oppose the old sedentary townsfolk. However, between the two a series of continuous transitions exists.

\subsubsection{Population Distribution}

The great majority of population tends to occupy southern piedmonts of mountain ranges of Tlemcen, where life conditions (climate, soil quality, level of natural resources, etc) are more or less favorable. They are also concentrated next highways (trunk roads, wilaya paths) leading to El-Aricha, Sebdou, Tlemcen). A part from the sparse populations and the watershed, we can say that the high plains are uninhabited. The average density rises to 7 inhabitants in $\mathrm{Km}^{2}$ El-Gor, El-Aricha and El-Bayadh. Everywhere else communal density seems lower because of strong dispersion of populations. Densities don't exceed 3 to 4 inhabitants in Km² (El-Aouedj, El-Aricha, El-Bayadh), they remain very scattered in the territory. Agglomerated populations represent higher densities:

- Whether in real urban structures,

- In old colonisation centers,

- Or, firmly, in hamlets.

Distribution of lower density zones displays a contrasted situation and opposes clearly two part separated by trunk road 22.

In the steppic plain, El-Aricha, Naama, El-Bayadh, Sebdou grew on the surface. The average annual extension can, sometimes reach $2.4 \mathrm{Ha}$. Hamlets, housing grouping seem to impose a lifestyle approaching that of agglomerations situated in the north. The extension of these hamlets and other groupings is, sometimes, rising more than the agglomerations. Highlands gather a weak population which seems to settle.

In the west, in the township of Beni-Snous, Azail, densities are, often between 6 to 9 inhabitants in $\mathrm{Km}^{2}$. The number is never below 5 inhabitants in $\mathrm{Km}^{2}$. The high plains till Ras El-Ma, El-Bayadh, are completely differents. Areas of settlement represent lower densities. Densities, rarely, exceed 3 inhabitants in $\mathrm{Km}^{2}$ (El-Aouedj, El-Aricha, El-Bayadh), especially in lower and flood places of the plain.

\subsubsection{Migratory Movements (Figure 2)}

Migratory phenomenon seems to affect all towns from Beni-Snous to El-Bayadh via El-Aricha and Mechria.

It is very difficult to know the migratory movements, their origin, and their rhythm. Census mention very little indications. So we did not consider places of birth or successive residences of inventoried persons. Partial and heterogeneous information are at our disposal. Before arriving to the desirable precision, some facts can be established, the outlines of migratory movements can be identified.

We notice that the population movements, generally, occur towards the agglomerations of the north, as Sebdou, Tlemcen, Sidi-Bel-Abbès. Migrants leave searching for an employment or an occupation. This happens, particularly with young people who remain residents in rural area but work in urban one. These movements 


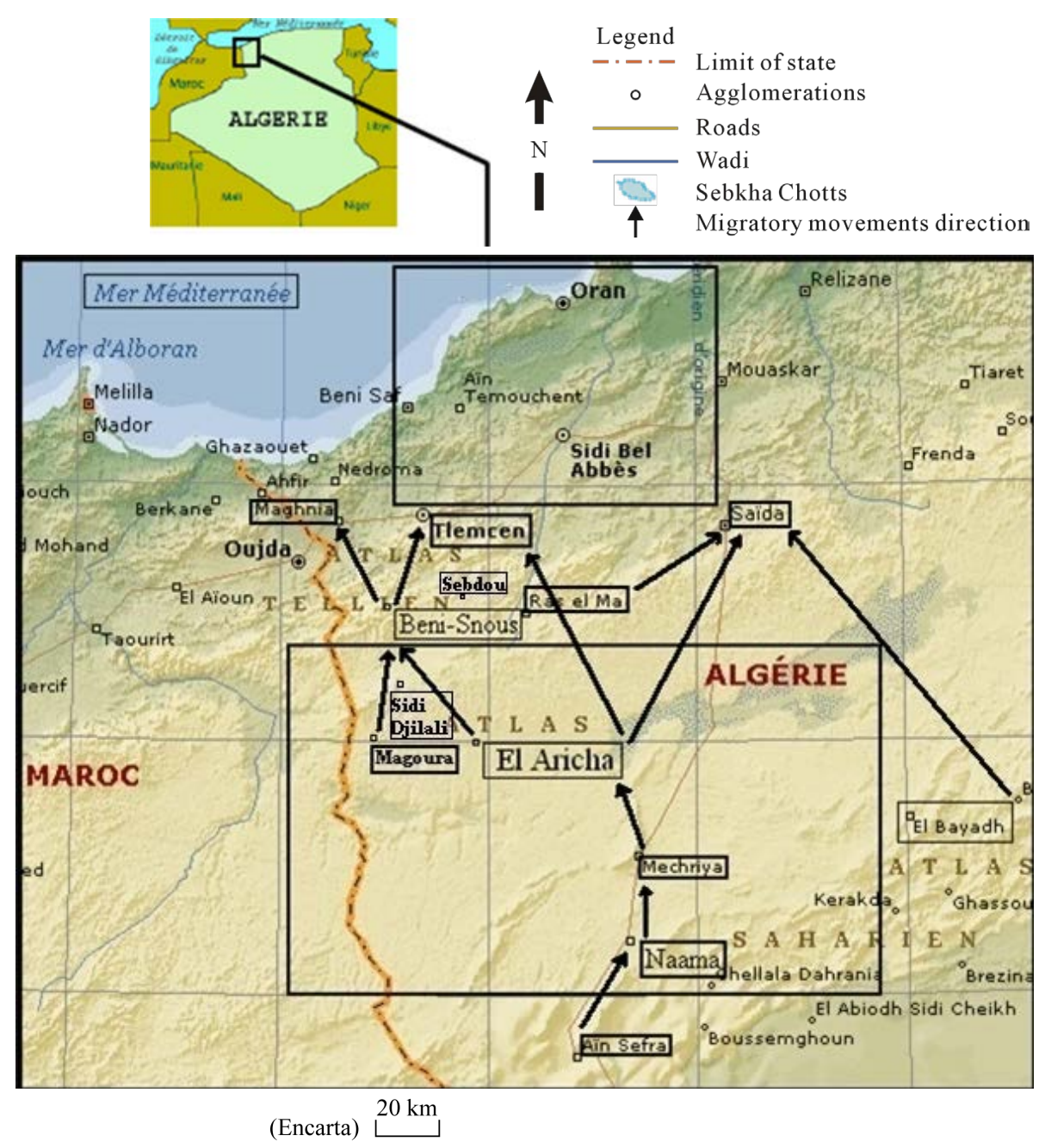

Figure 2. Migratory movements of population.

often, caused troubles in revenues and consumption habits in rural environment and resulted in abandonment of agro-pastoral employment.

Some migrations find obstacles. The state borders of young countries remain obstacles for traditional movements. The same tribe can have its different lineages scattered among several countries and cut from these traditional corridors of semi-nomadic movements.

Many semi-nomadic people are attracted by the standard of modern life and are themselves settled. Schooling as among the main reasons for this settlement because the educated youth do no more want to run after the sheep [4].

\subsubsection{Evolution of the Population}

Census data show that growth rate is rising through the years. Between 1987 and 2002, the population in Tlemcen (chief place of the region) increased from 111,588 to 137,578, which represents an increase of $18.89 \%$. In Sidi Djilali, the population rised significantly from 9504 to 11,433 between 1977 and 1987. The population densities seem to experience changes from one region to another. In the piedmonts of Sebdou and Sidi Djillali, the whole population reaches 13 inhabitants in $\mathrm{Km}^{2}$, and the dispersed population amounts to 5 inhabitants in $\mathrm{Km}^{2}$. Tlemcen and Beni-Snous have a high rate, 59 inhabitants in $\mathrm{Km}^{2}$.

Figure 3 shows a rise in population of El-Aricha, which increased from 4200 (1966) to 8500 (2008). From 1977 to 1987, the region experienced a significant decline of population from 6200 (1977) to 6050 (1987). This decrease may be the consequence of migrations searching for survival jobs (Figure 2). 


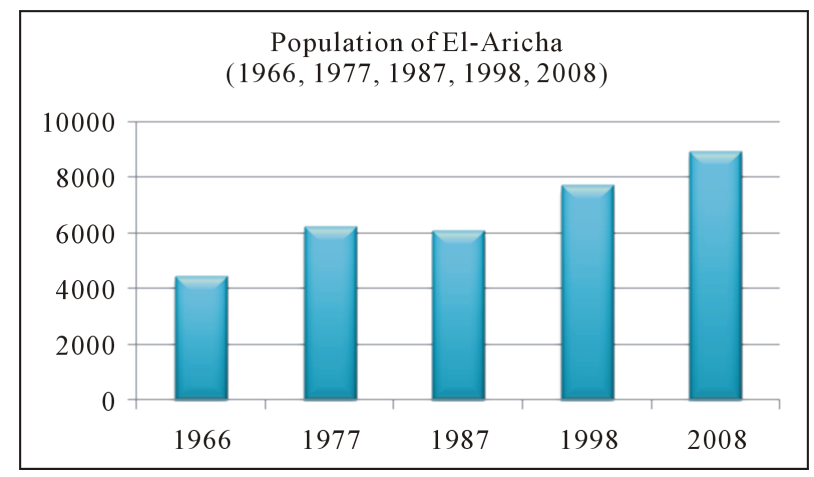

Figure 3. Evolution of steppic population from 1966 to 2008.

The largest majority of the population is concentrated in the main towns. This concentration causes a consumption of pre-forest land and rangelands. Population growth in regions concerned led to uncontrolled exploitation of the environment and inappropriate agricultural practices that leave no possibility for space regeneration.

\subsection{Vegetation and Botanical Characterization (Figure 4 and Figure 5)}

The human influence on vegetal formation have concerned some researchers among them: Benabdelli [23], Le-Houerou [24], Bouazza and Benabadji [25], Western [26], Haddouch, et al. [27], Robin, et al. [28], Ghezlaoui, et al. [29], Taleb Bendiab Sari, et al. [30], Regagba [4]. To try to know these phenomena, we will successively develop the botanic characters of found species (family, different biological and morphologic types).

\subsubsection{Families}

The distribution of families is heterogeneous. In the region of Beni-Snous, the most prevailing families are the Asteraceae with 14\% (Atractylis cancellata, Asteriscus maritimus, Centaurea pungens...), then the Grasses 10\% (Agropyron repens, Hordeum murinum, Aegilops triuncialis...), and then the lamiaceae 6\% (Teucrium fruticans, Teucrium polium, Sideritis Montana...), after that, there are other families poorly represented as the Oleaceae 3\% (Jasminum fruticans, Olea europea...), the buttercup 2\% (Adonis dentata, Ranunculus bullatus...).

At the level of steppic stations, the Asteraceae are in the first position with 24\% (Centaurea pullata, Atractylis cardius...), the Grasses in the second position with 12\% (Avenaalba, Dactylis glomerata...), the lamiaceae 10\% are in the third position (Salvia verbenaca, Ziziphora capitata...).

\subsubsection{Biological Types}

These biological types, in these formations, remain very heterogeneous. These spectra show a reduction, and a total absence of phanerophytes du, essentially, to degradation phenomena and to an increase of therophytes, especially at the level of some exploited stations.

In preforest stations of Beni-Snous, we notice a dominance of therophytespecies (49\% as, Avena sterelis, Agropyron rupens, Bromus rubens, Hordeum murinum, Chenopodium album, Adonis dentata...). The chamaephytes (25\%) are in the second position: Ulex bovinii, Cistus ladaniferus, Cistus villosus, Cistus monspeliensis, Erica arborea...). Geophytes with 11\% occupy the third place (Urginea maritima, Asparagus albus, Asparagus acutifolius, Allium roseum, Allium nigrum...). Phanerophytes (Quercus ilex, Quercus coccifera) and hemicryptophytes have $8 \%$ and $7 \%$. Spectra composition of the studied part accuses a predominance of therophytes over chamaephytes, hemicryptophytes and phanerophytes. It confirms the degraded pre-forest character.

The steppe is dominated by therophytes (73\%, Alyssum campestre, Atractylis carduus, Centaurea pullata, Herniaria hirsuta...), the chamaephytes are in second position with 19\% (Astragalus armatus, Eryngium matritimum, Echinops spinosus, Artemisia herba-alba, Stipa tenacissima...). Hemicryptophytes (7\%) are represented by Dactylis glomerata, Paronychia argentea... Hemicryptophytes are very weak, represented by number 2 in Sidi-Djilali and 3 in Nedroma, this can be explained by a soil poor in organic matter. This phenomenon was confirmed by Barbero [31]: "Indeed, the abundance of hemicryptophytes reflects a wealth of organic matter in forests and a high altitude”. 

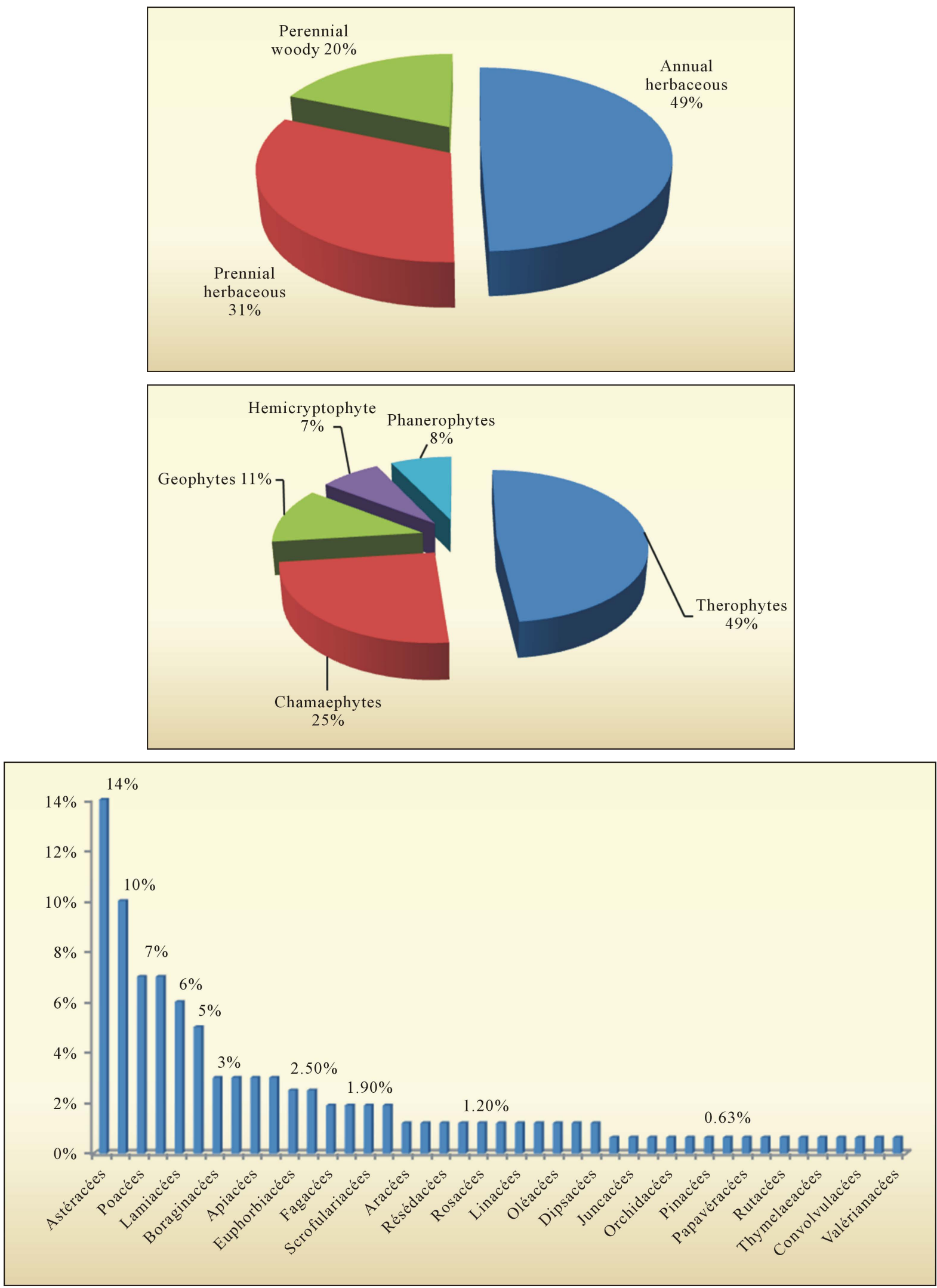

Figure 4. Biological types, morphological and family "Béni-Snous”. 

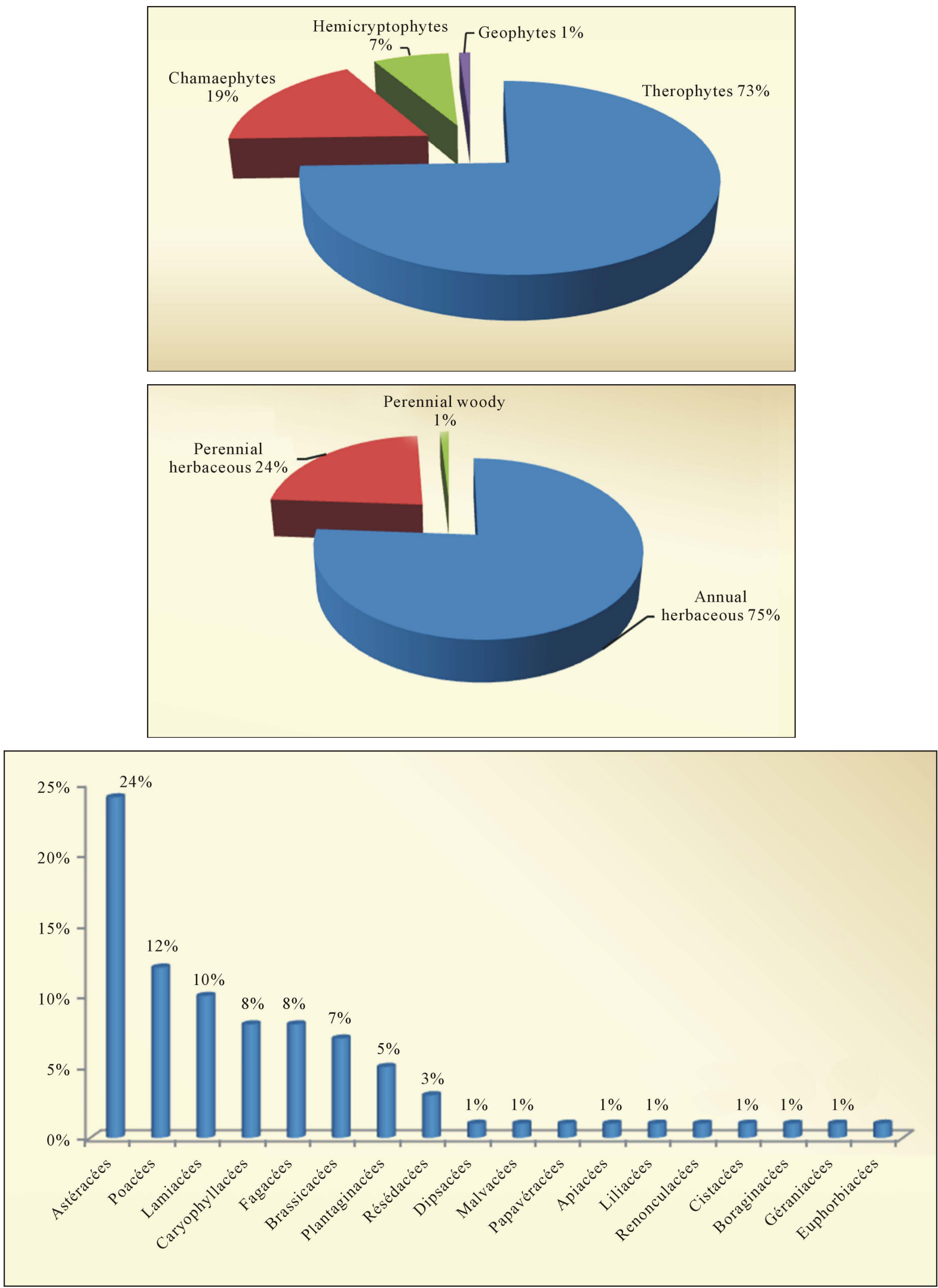

Figure 5. Biological types, morphological and family "El-Aricha”. 
Despite the importance of therophytes, the chamaephytes keep an important place in psammophile vegetal formation. They are better adapted to aridity. The harsh climate and structural instability of the ground support the development of short-cycle species, more or less demanding in water and trophic needs.

\subsubsection{Morphological Types}

There are three morphological types:

In Beni-Snous these morphological types are distributed as follows:

- Annual herbaceous (49\%) as Avena sterilis, Arsarum vulgare...

- Perennial herbaceous (31\%) as Juncus maritimus, Allium nigrum

- Perennial woody (20\%) as Pinus halepensis, Quercus suber

Vegetal formations are marked by their heterogeneity between woody and herbaceous, in one hand, and perennial and annual in another hand. Perennial annual species dominate with $46 \%$.

In the steppic region (El-Aricha and El-Bayadh), these morphological types are distributed as follows:

- Annual herbaceous (75\%) as Alyssum campestre, Ceratocephalus falcatus...

- Perennial herbaceous (24\%) as Stipa tenacissima, Reseda phyteuma...

- Perennial woody (1\%) as Juniperus oxycedrus...

Annual vegetation outweigh in the steppic region. They represent $75 \%$. Annual perennial species are placed in the second position with $24 \%$.

\subsection{Crafts and Agro-Pastoral Activities}

\subsubsection{Crafts}

In this pre-forest and steppic environment, plants occupy the most important part in the matter supply, especially alfa (Stipa tenacissima) and Saw Palmetto (Chamaerops humilis) for the manufacturing of mat. The artisans use various plants for their coloring materials, it is the Arbousier shrub (Arbutus unedo), mulberry fruit (Morus al$b a$ ) for obtaining a color both reddish and blackish when the fruits are ripe. Manufacture of traditional artisanal dyeing uses vegetal substances, bark grenades, the root of walnut (Uglands regia) which produce the yellow color. Vegetable plants for handicraft use exist in abundance in the region.

\subsubsection{Agro-Pastoral Activities and Their Impact (Figure 6, Pictures 1-3)}

The lack of balance between the actual load of herds and pastoral possibility of these massive forest meadow

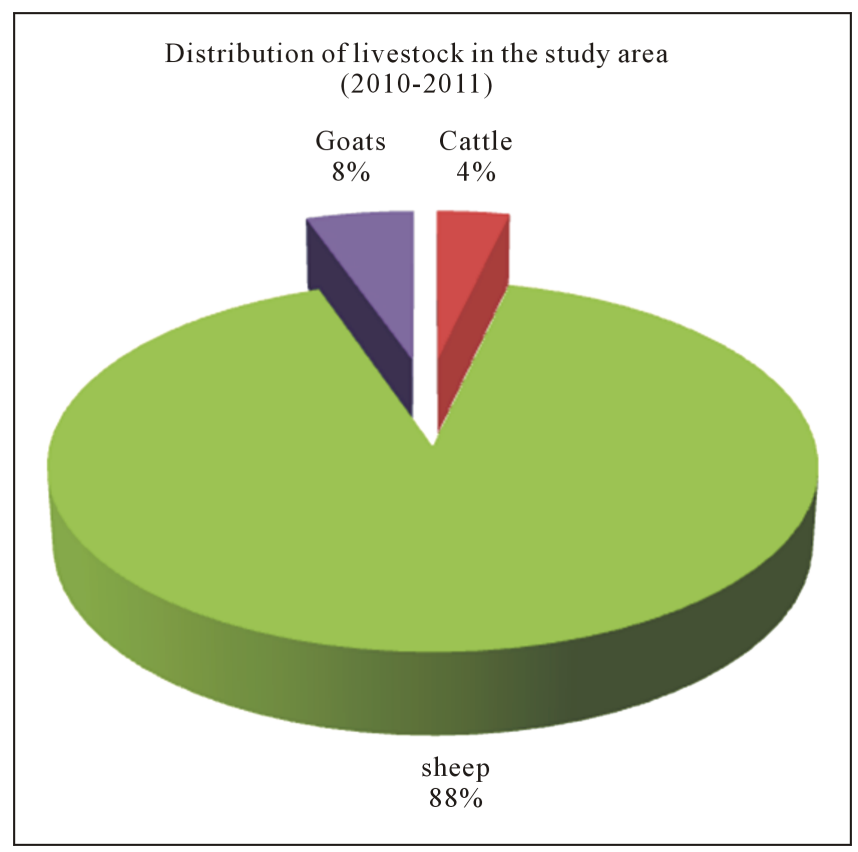

Figure 6. Livestock evolution of the steppe from 1987 to 2008. 


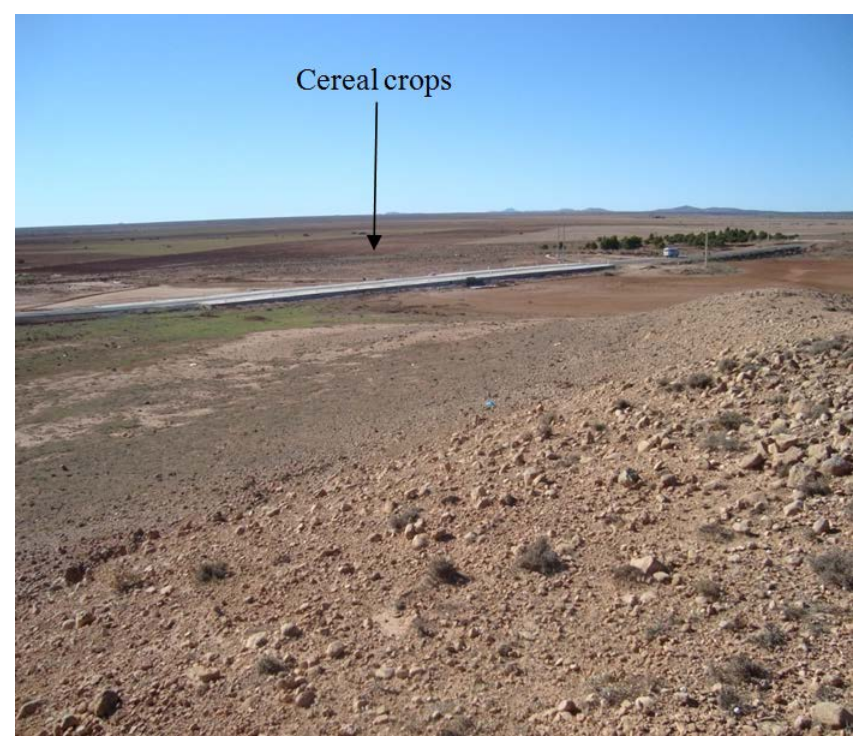

Picture 1. Degraded steppe.

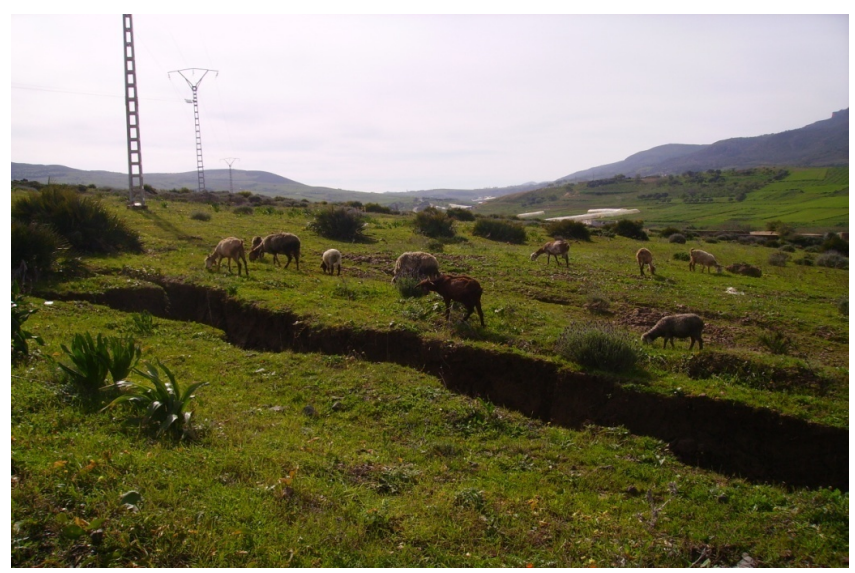

Picture 2. Overgrazing in mountains.

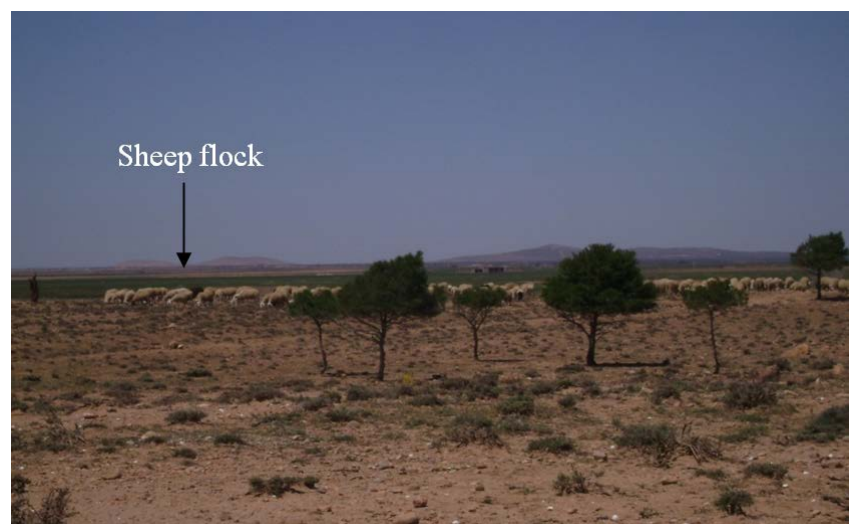

Picture 3. Overgrazing in steppe.

which constitute about $30 \%$ of natural rangeland, which results in overgrazing, soil compaction, lack of regeneration, aging plantations, can rise from three to four times according to the regions. In these mountains, the pastoral charge, always, remains worrying and may cause environmental degradation. Herd composition shows an 
overwhelming predominance of small livestock, particularly sheep which occupy about $75 \%$ of the number of herds Aidoud Lounis [32]. These lasts are more and more concentrated in very small spaces exercising a strong pressure on the environment. Figure number 6 also shows strong domination by sheep (88\%), goats (8\%), and finally cattle (4\%).

The steppes of North Africa occupy more than 63 million hectares of low and sparse vegetation submitted to very old human exploitation. The above ranching of sheep and goats has been the historical vocation of the steppes. This situation has endured for centuries until the mid 20th century Aidoud, et al. [33]. Cultures seem to stretch on surfaces where the forest has existed and where grazing pressure has significantly increased. This is generally based on extensive livestock transhumance and breeders who are at the same time farmers. Courses are exploited by a very important charge of animals. Open to public (pickers, walkers, etc.) these matorrals, by the succeeding of continual population growth of agglomerations, trampling, and degradations multiply.

Clearing of pre-forest lands for the benefit of cultures (cereal and food) affects more than $20 \%$ of areas and tends to make them very vulnerable. Sometimes as a result of reductions in rangeland, anthropogenic pressure causes overgrazing in these silvo pastoral ecosystems. Despite its important economic role, the agricultural sector still faces structural problems (land structures) and natural ones.

Transformations of vegetation are related to the evolution and extension of cultures, loss of forest areas, changing rural landscapes, anarchic recolonisation of environments through infrastructure (urbanization matorrals). Thinning forests are recovered for agriculture and procurement of firewood.

The slow regeneration of perennial species also causes a change of vegetation. These perennials are marked by heterogeneity between the woody and herbaceous and between perennials and annuals, but also by the harsh climate promoting the development of herbaceous species of short cycle at the expense of perennial woody generally more demanding in water and trophic needs. Disturbances which affect the mountains of our regions (Tlencen, Béni-Snous, Sebdou and Sidi Djilali) caused diversification of the floristic procession (4. Vegatation and activites).

Proliferation of thorny or toxic species is accelerating, sometimes with the dominance of: Calycotome spinosa, Chamaerops humilis, Echinops spinosus, Asparagus albus, Ulex bovini, Cistus villosus, Asphodelus microcarpus, Urginea maritima, Atractylis humilis, Centaurea incana.

\subsubsection{Fire}

By its floristic composition, the area of study could not escape the fires. The annual average of burned areas represents 120 hectares for the period between 1992 and 2004. Most of these fires are due to human negligence related to pyromania. The causes of forests fires are known and the works of Amouric [34] are applied for giving summary review, among the most recent, we mention:

- Increases in frequency tend to accelerate in the summer during critical periods;

- The penetration routes of most forests;

- Pyromania;

Climatic conditions play an important role first in the fires and their inter-annual and inter-regional irregularities.

It seems that, apart from pyrophytiques formation represented by Pinus halepensis, Cistus ladaniferus, Cistus villosus, Thymus ciliatus, the presence of the Lamiaceae, Papilionaceae and Cistacées can also accelerate fires.

\subsubsection{Threats of Ecosystem}

Among the formation corresponding to further stages of degradation, before the bare earth, we can mention:

- the ermes with Ampelodesma mauritanicum, Asphodelus microcarpus and Urginea maritima, presenting sometimes release of green oak and some species of matorrals

- Lawns with Filago pyramidata et Plantago lagopus

- Lawns with Bromus rubens, etc.

The actual human pressure (overgrazing and cultures) do not allow them to reconstruct forestry or pre-forest groups to which they belong. It seems that the actual climatic conditions are not a favorable factor in this reconstruction.

At matorralisation resulting from foresty and pre-forest structures, rapidly succeed a dematorralisation with a complete extinction of woody other than softwood and the appearance of some species which announce the steppisation (phenomenon observed in the steppe of El-Aricha and El-Bayadh). This last is characterized in the 
mountains of the region by the development of Stipa tenacissima de Artemisia herba-alba, and sometimes more in the south (towards Mecheria, Naama, El-Aricha) of Noaea mucronata and Lygeum spartum, according to the type of soil.

\section{Conclusions}

The high altitudinal position (more than 900 meters) of these regions de Beni-Snous, Tlemcen, Sebdou and Magoura remain submitted to continental and Saharan influences by imposing an increasing aridity from north to south and from the west to the east. The dryness is accentuated by an annual and inter-annual variability of rain (mentioned in rainfall precipitations paragraph).

By comparing the floristic inventories realized in 1980 and 2004 in the same stations, it has been shown that this type of vegetation was enriched in therophytes (73\%) and showed at the same time, a degradation and a further desiccation. This dynamic trend of vegetation will be the consequence of climatic progressive seasonal modifications which are more arid continuing today. Woody perennials do not exceed $10 \%$ in mountainous areas (Béni-Snous) and 2\% at the level of the steppe (El-Aricha, Naamaet El-Bayadh).

The seasonal aridity is much responsible for the great architectural diversity of potential forest stands where coexist sclerophyllous, deciduous and laurifoliés forests.

Landscapes of these matorrals in the region of Beni-Snous tend to regress. The balance of the area in question, of mountains and steppe is related to the combined action of climatic hazards and especially to anthropic factors. The interest that we have for these pre-forest vegetations is confirmed by the poor condition of their stands. Indeed deforestation concerns all the climatic areas observed in the mountains of Beni-Snous, of Tlemcen, Sebdou, El-Bayadh and El-Aricha.

Environments banning to livestock, as well as reforestation with indigenous plant species in mountainous ares (southern Sebdou), would surely have positive effects on biological climb.

It would be desirable, in the future, to predict a management policy of steppic ecosystems restoration by observing rotations course along time at the level of steppic zones (El-Aricha, Mecheria and El-Bayadh) and especially avoiding uncotrolled agriculture caused by plowing and setup of cereal crops in these quite degraded lands.

\section{References}

[1] Barbéro, M., Bonin, G., Loisel, R. and Quézel, P. (1990) Changes and Disturbances of Forest Ecosystems Caused by Human Activities in the Western Part of the Mediterranean Basins. Vegetatio, 87, 151-173. http://dx.doi.org/10.1007/BF00042952

[2] Barbéro, M., Loisel, R. and Quézel, P. (1990) Les apports de la phytoécologie dans l’interprétation des changements et perturbation induite par l’homme sur les écosystèmes forestiers méditerranéens. Forêts méditerranéennes, XII, 194216.

[3] Long, G. (1975) Diagnostic phytoécologique et aménagement du territoire : Principes généraux et méthodes. Collection Ecologie, Ed. Masson, Tome 1, 225 p.

[4] Regagba, Z. (2012) Dynamique des populations végétales halophytes dans la région sud-est de Tlemcen, aspects phytoécologiques et cartographiques. Thèse Doct. Etat Bio. Univ. Tlemcen, 169 p.

[5] Benest, M. and Elmi, S. (1969) Précisions stratigraphiques sur le Jurassique inférieur et moyen de la partie méridionale des monts de Tlemcen (Algérie). Ext. Sém. Soc. Géol., France.

[6] Benest, M. (1985) Evolution de la plate forme de l’Ouest algérien et du Nord Est marocain au cours du Jurassique supérieur et au dé but du Crétacé: Stratigraphie, milieux de dépôts et dynamique sédimentaire. Doc. Lab. Géol. Fac. Sci., 95.

[7] Ruellan, A. (1970) Les sols à profil calcaire différencié des plaines de la basse Moulouya. Thèse Doc., Etat Univ., Strasbourg, $482 \mathrm{p}$.

[8] Aubert, G. (1965) Classification des sols : Tableaux des classes, sous classes, groupes et sous groupes des sols utilisés par la section de pédologie de l’ORSTOM. Cah. ORSTOM, Série pédologie III, 269-288.

[9] Duchaufour, Ph. (1977) Pédologie. Tome I. Pédogenèse et classification. Ed. Masson, Paris, 477 p.

[10] Seltzer, P. (1946) Le climat de l’Algérie. Inst. Météo. Et de Phys. Du globe. Univ. Alger, 219 p.

[11] Bary-Lenger, A., Eurard, R. and Gathy, P. (1979) La forêt vaillant. Carmane. Imprim, Liège, 611 p.

[12] Debrach, J. (1953) Notes sur les climats du Maroc occidental, Maroc méridional. 32-34, 1122-1134. 
[13] Bagnouls, F. and Gaussen, H. (1953) Saison sèche et indice xérothermique. Doc. Carte port. Vég. Art. 8. Toulouse, 47 p.

[14] Maire, R. (1952) Flore de l’Afrique du Nord. Encyclopédie biologique. Ed. Le Chevalier, Vol. I, Paris VI, 1-7.

[15] Quezel, P. and Santa, S. (1962) Nouvelle flore de l’Algérie et des régions désertiques méridionales. 2 tomes. Ed. C.N.R.S. Paris, 1170 p.

[16] Gaston, B. (1990) La grande flore. Ed. belin, Paris, 4 tomes + annexes.

[17] Raunkiaer, C. (1904) Biological Types with References to the Adaptation of Plants to Suivre the Unfavorableseas on. In Raunkiaer, 1934, 1-2.

[18] Bouchenak-khelladi, A.B. (2008) Le parler amazigh de Béni-Snous. Etude phonétique et phonologique. Mag. Univ. Tlemcen, $226 \mathrm{p}$.

[19] Boukhobza, M. (1982) L’agropastoralisme traditionnel en Algérie, OPU, Alger, 468 p.

[20] Bourdieu, P. (1986) Sociologie de l’Algérie. Ed. Que sais-je? PUF, Paris, 127 p.

[21] Salem, C. (1991) Encyclopédie berbère, “Béni Snous”. in 10 Beni Isguen-Bouzeis, Aix-en-Provence, Ed. Sud, 14681470.

[22] Bellissant, R. (1941) Béni-Snous, Causerie, texte et photos. 43 p.

[23] Benabdelli, K. (1983) Mise au point d’une méthodologie d’appréciation de la pression anthropozoogène sur la végétation de la région de Telagh (Sidi Bel-Abbès, Algérie). Thèse de spécialité Ecologie. Fac. Sci. Et Tech. St Jérôme, Marseille, $185 \mathrm{p}$.

[24] Le Houérou, H.N. (1992) Vegetation and Land Use in the Mediterranean Basin by the Year 2050. A Prospection Study. In: Jeftic, L., Milliman, J.D. and Sestini, G., Eds., Climatic Change and the Mediterranean, Edward Arnold, London.

[25] Bouazza, M. and Benabadji, N. (1992) Composition floristique et pression anthropozoïque du sud-Ouest de Tlemcen. Rev. Sci. Tech., University of Constantine, Algérie, 93-97.

[26] Western, D. (2001) Human-Modified Ecosystems and Future Evolution. Proceedings of the National Academy of Sciences of the United States of America, 98, 5458-5465. http://dx.doi.org/10.1073/pnas.101093598

[27] Haddouche, I., Mederbal, K. and Saidi, S. (2007) Space Analysis and the Detection of the Changes for the Follow-Up of the Components Sand-Vegetation in the Area of Mecheria, Algeria. Revue SFPT N 185 (2007-1).

[28] Reid, R.S., Galvin, K.A. and Krusta, R.S. (2008) Global Significance of Extensive Grazing Lands and Pastoral Societies an Introduction. Consequences for Human Natural Systems. USA, 1-24.

[29] Eddine, G.B., Benabadji, N., Benmansour, D. and Merzouk, A. (2006) Analyse des peuplements végétaux halophytes dans le Chott El-Gharbi (Oranie-Algérie) Rev. Acta Botanica Malacitana, 36, 113-124.

[30] Sari-Ali, A.T.B., Benabadji, N. and Bouazza, M. (2012) Floristic Composition of the Halophilic and Salt-Resistant Plant Population in Hammam-Boughrara (Oran-Algérie). Open Journal of Ecology, 2, 96-108. http://dx.doi.org/10.4236/oje.2012.22012

[31] Barbéro, M. (1992) Matorralisation et aridification des écosystèmes méditerranéens. Actualités et perspectives. Les recherches en France sur les écosystèmes forestiers. Document du Ministère de l'Agriculture et de la forêt, 55-56.

[32] Lounis, F.A. (1997) Le complexe alfa-armoise-sparte des steppes arides d'Alger: Structure et dynamique des communautés végétales. Thèse doct. Univ. Aix-Marseille III, 263 p.

[33] Aidoud, A., Le Floc’h, E. and Le Houérou, H.N. (2006) Les steppes arides du Nord de l’Afrique. Rev. Sèch. 17, 19-30.

[34] Amouric, H. (1985) Les incendies de forêts d'autrefois. Datar (MIPAENM), 15-51. 
Scientific Research Publishing (SCIRP) is one of the largest Open Access journal publishers. It is currently publishing more than 200 open access, online, peer-reviewed journals covering a wide range of academic disciplines. SCIRP serves the worldwide academic communities and contributes to the progress and application of science with its publication.

Other selected journals from SCIRP are listed as below. Submit your manuscript to us via either submit@scirp.org or Online Submission Portal.
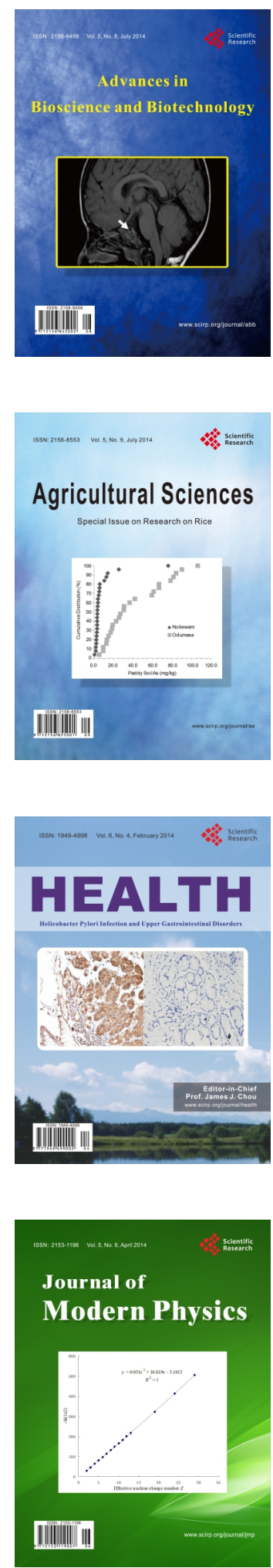
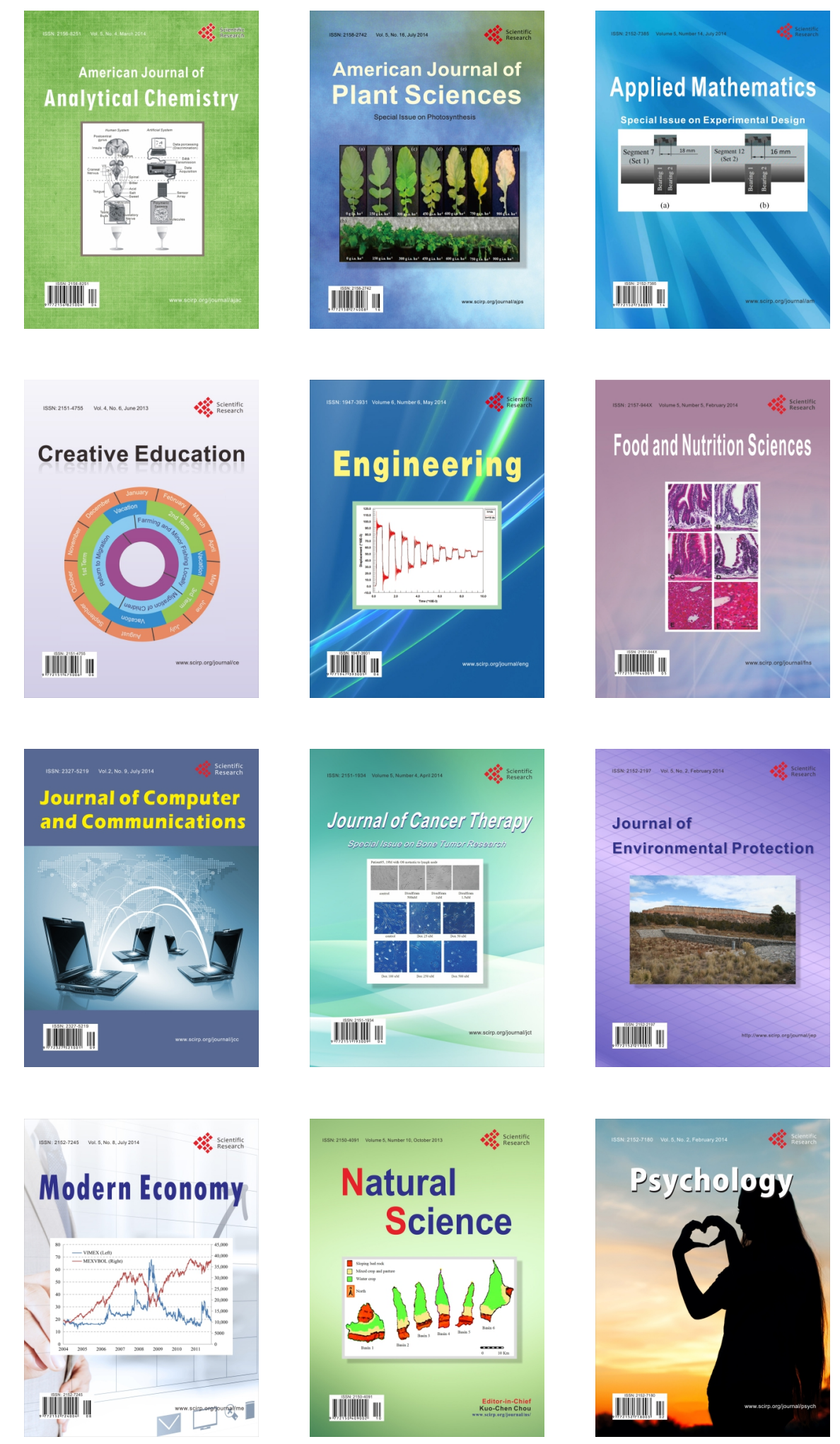